\title{
Russian topographic mapping in Finland 1870-1917
}

\author{
Jakobsson Antti ${ }^{\text {a }}$ \\ ${ }^{a}$ National Land Survey of Finland, antti.jakobsson@ @ nls.fi
}

Keywords: Topographic mapping, Senate maps, Struve geodetic chain

\begin{abstract}
:
The Senate Maps are based on a survey launched by Russian topographers in 1870, which continued until Finland's independence in 1917. For the first time, these maps were based on geodetic measurements, which had already begun in 1860. They also utilized the Struve geodetic chain, a large triangulation chain between the Black Sea and the Arctic Ocean, made between 1816-1855. The Finnish Senate (then the government in Finland) funded the survey and Finland was the only country to receive two photocopies of maps made by the Russians. The survey was considered important because it accounted for $2 \%$ of the whole revenues to the Senate's budget. It was also exceptional that the Finns led this mapping work in Finland and they also led the mapping work elsewhere in Russia. These officers were Alexander Järnefelt (1883-1896) and Axel Edvard Bonsdorff (1839-1919). Järnefelt participated to Russo-Turkish War in 18771878 and led the mapping of Bulgaria with 180 topographers and Bonsdorff mapped Bessarabia (Moldova) in 1882 and established the observatory of Tashkent. Russian topographic mapping has been studied earlier by Ek (1981), Postinikov (1993), Saarentaus (1981), Strang (2014) and Harju (2017) but no general publication has been available before the author published a book on Senate maps in 2020.
\end{abstract}

The mapping work initiated by Russia was extensive and covered the entire Russian border areas of Europe (Figure 1). The printed maps were published in Russian and were secret. However Russian topographers published quite openly the coverage maps in the publication Zapiski voenno-topografičeskago otdela Glavnago upravlenija General'nago štaba. In Finland there are copies of this publication between 1878-1916. Also, geodetic work for the maps were discussed and published. The place names for the Senate maps was changed to Finnish and Swedish. They were colored by the National Board of Survey and supplemented throughout that time with major changes such as the railways.

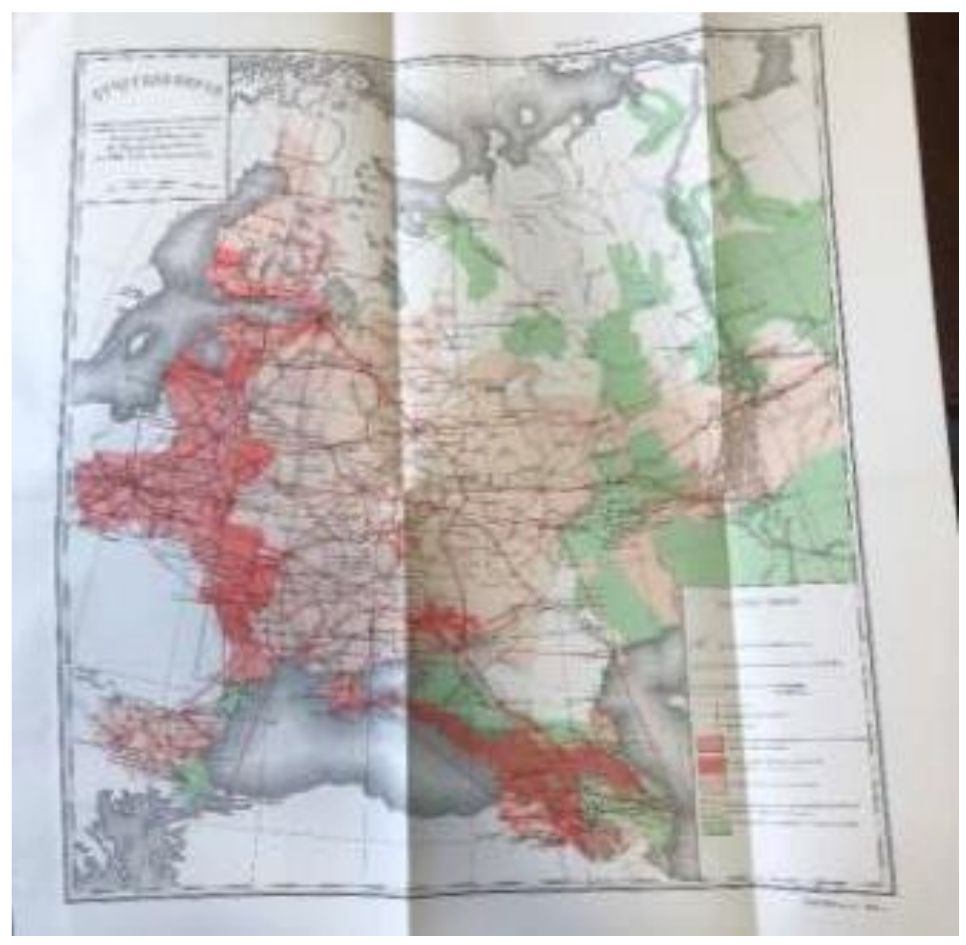

Figure 1. Coverage of Russian topographic mapping in Europe 1912. Source: Zapiski voenno-topografičeskago otdela Glavnago upravlenija General'nago štaba 1914. 
There was a plan to cover most of the Finland, but the work was not completed before the first World War. Just before the revolution in Russia, a rapid mapping effort was made which produced maps in 1:42 000 scale in Aland Islands, the Eastern and Central Finland. The maps of Eastern Finland were printed in scale 1:84 000. The maps concerning Central Finland have not be found so far.

Based on Senate maps, "Finnicized" maps were published after the independence, but because they were black and white and extensive surface markings, quite difficult to read. However, these maps were the only accurate maps in many places in Southern Finland until the 1960s, when they were replaced by the new basic map. After the independence, printed maps were also on sale because they had been obtained in large quantities as war booty. For the first time, these maps show the exact shape of the terrain with elevation curves, including buildings (crofts, farmhouses and manors) and the road are accurately described. The Senate maps were nicely hand colored. Two different coloring versions were made; one according to the Russian standard and one according to the Finnish standard.
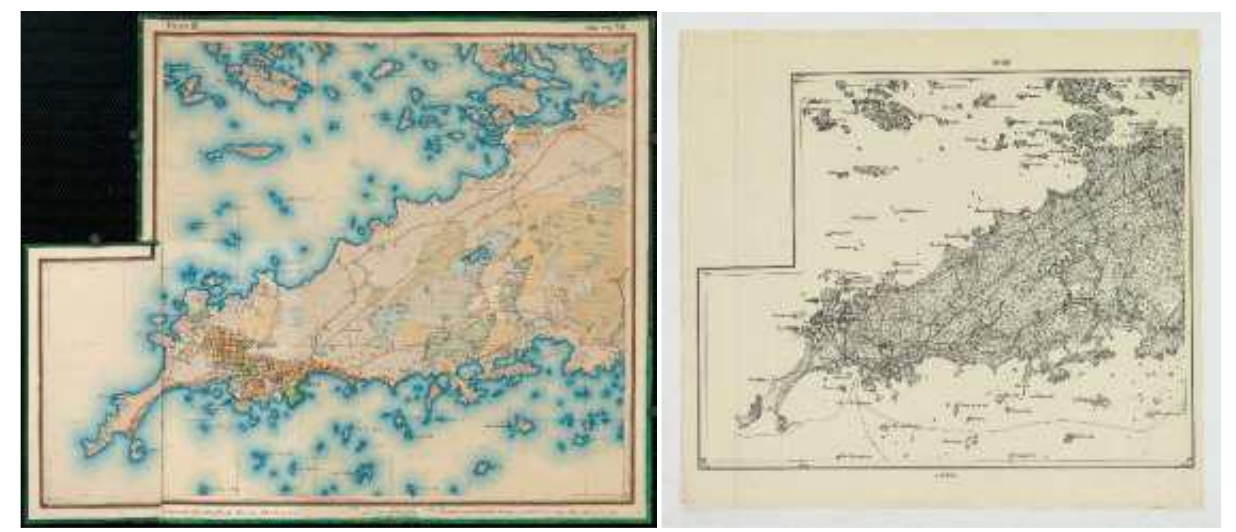

Figure 2. Senate map 1:21 000 with Finnish place names III 20 Hanko (hand colored) and printed 1:42 000 in Russian. After the second World War all maps presenting the former Finnish Carelia had to be ceded to the Soviet Union. Among

other maps, Senate maps were ceded and some of the maps were cut align the new border. Location of these maps in Russia is not know in Finland. Also, Russian hand-colored originals are still not available in Russia.

\section{References}

Ek, Heli, 1981. Venäläiset topografiset kartat - tutkielma venäläisten sotilasviranomaisten Suomesta vuosina 17981917

laatimista topografisista kartoista. Teknillisen korkeakoulun maanmittausosastolla tehty diplomityö, Espoo, 1981. Harju, E-S., 2016. Suomen sotilaskartoitus 400 vuotta. Atlasart, Viljani, 2016.

Jakobsson, A., 2020. Senaatin kartat 1870-1917 Uusimaa [Senate maps 1870-1917 Uusimaa], AtlasArt, 2020,256 p.

Postnikov, A., 1993. Contact and Conflict: Russian mapping of Finland and the development of Russian cartography in the 18th and 19th centuries. Fennia vol 171 no 2, 1993.

Postnikov, A.,2018. The Corps of Military Topographers of the Russian Empire, LAP Lambert Academic Publishing, 2018.

Saarentaus, T., 1981. Russian topographic mapping of Finland before World War I. Papers of the Nordenskiöld seminar on the history of cartography and the maintenance of cartographic archives, Espoo (Finland), September 12-15, 1979 edited by Kerkko Hakulinen and Arvo Peltonen, Helsinki, 1981.

Strang, J., 2014. Venäjän Suomi-kuva - Venäjä Suomen kartoittajana 1710-1942. Antiikki-Kirja, Helsinki, 2014.

Wheeler, M., 1885. Third International Geographical Congress and Exhibition at Venice, Italy 1881, accompanied by data concerning the principal government land and marine surveys of the world. Washington 1885. 